Journal of Contemporary Research in Social Sciences

ISSN : 2641-0249

Vol. 3, No. 4, pp. 114-124.

2021

Publisher: Learning Gate

DOI: 10.33094/26410249.2021.34.114.124

(C) 2021 by the authors; licensee Learning Gate

\title{
Key Vulnerabilities and the Competitive Advantage among Commercial Banks in Kenya
}

\author{
Paul Waithaka \\ Department of Business Administration, Kenyatta University, Kenya. \\ Email: paulwaithaka82@yahoo.com
}

Received: 2 August 2021; Revised: 30 August 2021; Accepted: 13 September 2021; Published: 28 September 2021 Abstract: Globalization and technological advancement have in a big way altered the business landscape, making it difficult for banks to sustain competitive advantage. The need to enhance competitiveness has forced banks to consider competitive intelligence not only as a tool to guard against threats but also as a mechanism for discovering new opportunities and trends. Competitive intelligence contributes to continuous improvement of the quality of products, services and solutions offered by banks to their clients as well as increasing a firm's innovative capability. Key vulnerabilities have been identified as one of the strategic inputs of competitive intelligence that a firm needs to focus on in order to gain and sustain competitive advantage. This paper sought to examine the effect of identification and assessment of key organizational vulnerabilities on the competitive advantage among commercial banks in Kenya. The target population for the study were directors or managers in-charge of planning or strategy in each of the forty banks in the country. Primary data was collected using a semi structured questionnaire. The questionnaire was tested for both validity and reliability and was found to meet the required threshold. A response rate of $77.5 \%$ was achieved in the study and this was adequate for analysis. The study found that identification, assessment and hedging against key vulnerabilities had significant effect on the ability of banks to sustain competitive advantage. The study therefore concluded that key vulnerabilities should be identified, assessed and hedged against since they could inhibit a company's strategy from succeeding in the marketplace. The study recommends that banks should raise the level of use of competitive intelligence in monitoring the competitive landscape to enable early identification and assessment of key vulnerabilities, then take steps to hedge the vulnerable areas from being exploited by rivals to the detriment of the bank. The study further recommends that managers should be continuously assessing the vulnerability of their banks with aim of hedging against attack by rivals.

Keywords: Key vulnerabilities, Strategic inputs of competitive intelligence, Competitive advantage.

\section{Background of the Study}

The increased environmental uncertainties have created a need to monitor and understand the environment more accurately for survival and success (Kalinowski, 2012). This recognition of the environmental challenges and risks that have continued to increase has brought a need for the companies to seek for advanced competencies to continuously monitor the competitive landscape to remain competitive (Heppes, 2006). The need to enhance competitiveness has forced companies to consider competitive intelligence not only as protective tool to guard against perceived threats and changes but also as a mechanism for discovering new opportunities and trends (Pirttimäki, 2007). Garelli (2003) states that since companies actually compete in the global economy, many authors are of the opinion that when studying competitiveness, the focus should be on companies as they are the main engines of a country's competitiveness. 
Competitive intelligence has become a very important tool in the organization strategic planning and management processes (Safarnia, Akbari, \& Abbasi, 2011). Nenzhelele (2012) noted that there was an increase in the number of organizations carrying out competitive intelligence activities either formally or informally due to its benefits. Knowledge and information have become vital elements in wealth creation by organizations. Through utilizing information systems, the abundance of available information would enable organizations to generate competitive advantage and constant innovations to survive and prosper in the long term (Laudon \& Laudon, 2007).

Wright (2010) state that there are many reasons that motivates business enterprises to use competitive intelligence stating that it provides: "an objective view of the market place; a reduction in decision making time, minimizing risk and avoiding surprises; identification of opportunities before the competition does; identification of early warning signals of competitor moves; time to consider counter moves; input to idea generation; challenges to, and/or verification of, assumptions; challenges to, and/or verification of intuition; a proactive decision making attitude; support for prioritization of decisions; stimulation for pursuing improvement rather than mediocrity; a reduction in uncertainty.

The challenge for organization's management today in their quest to improve performance is how to deal with this changing competitive landscape. Performance measurement is considered as the process of quantifying the effectiveness and efficiency of actions (Alaa \& James, 1996). Ma (2000) observed that competitive advantage and firm performance are two constructs with an apparently complex relationship, while Ray, Barney, and Muhanna (2004) found a significant relationship between competitive advantage and performance. Though much empirical works have centred on competitive advantage, the generalization of its relationship to competitive intelligence is under researched (Safarnia et al., 2011). Competitive intelligence is the value adding, continuous, and systematic process of knowledge and information flow for the purpose of monitoring both the internal and external environment of an organization collected legally and analyzed and finally used to improve decision making (Roitner, 2008).

\subsection{Strategic Inputs of Competitive Intelligence}

The topic of intelligence is vast and has its roots in military science. One of the earliest sophisticated references is the art of war by Sun Tsu (Griffith, 1971) written about $500 \mathrm{BC}$ and has been the basis for development in military intelligence. Intelligence has been a significant factor in military success for thousands of years (McCandles, 2003). The genesis of intelligence activities in the context of commerce and business, is however, a more recent development (Fleisher, 2001). Since the end of the Cold War, competitive intelligence once used in the military environment rapidly infiltrated into the business environment (Deng \& Luo, 2010). When the Cold War came to an end in 1990, downsizing occurred in the United States of America armed forces and related intelligence activities, which resulted in many qualified intelligence officers seeking to apply their skills in other arenas. One arena where they found a home was in business organizations (Prescott, 1999). Hence the widespread use of competitive intelligence in business organizations today.

Pertisor and Strain (2013) noted that competitive intelligence contributes to the continuous improvement of the quality of products, services and solutions offered by companies, while on the other hand, has an important role in increasing the firm's innovation capability. Fahey (2007) identified five competitive intelligence domains or strategic inputs that researchers in competitive intelligence needs to focus on. These are: marketplace opportunities; competitor threats; competitive risks; key vulnerabilities and core assumptions.

Pirttimaki and Hannula (2003) stated that one of the objectives of competitive intelligence is to enable managers understand where the organization is vulnerable. Assessing key vulnerabilities requires the identification of that which could most critically affect the organization's strategy and to which management has least control. This compels managers to go beyond listing those entities but to analyze and rank current and potential threats and risks to enable identification of those that could most severely impede strategy success. Waithaka (2020) states that tactics oriented competitive intelligence 
could inform a firm's sales force where the next generation of products could be heading. Every manager should understand one of the principles of Sun Tsu, who urged military generals to avoid what is strong and attack the weakest part of the rival. Carrying out a SWOT analysis would assist managers to understand the issues facing an entity that may affect the strategy.

\subsection{Competitive Advantage}

The pursuit of competitive advantage is an idea at the very heart of strategic management literature (Liao \& Hu, 2007). However Ma (2000) states that competitive advantage is perhaps the most widely used term in strategic management yet remains poorly defined and operationalized. Levy and Weitz (2001) describe sustainable competitive advantage as an edge over competition that could be maintained over a long time. In order for the organizations to create sustainable competitive advantage, they need to develop a value propositioning that meets the needs of customers in a way that rivals cannot match or easily imitate (Kotler \& Kelley, 2006). It is essentially a position of superiority on the part of the firm in relation to its competition in any of the multitude of functions/activities performed by the firm. Ma (2000) categorizes generic competitive advantages into three: ownership based; access- based and proficiency-based.

As noted by Porter (1996), at the most basic level, firms create competitive advantage by perceiving or discovering new and better ways to compete in an industry and bringing them to the market, which is ultimately an act of innovation, shifts competitive advantage when rivals fail to perceive the new way of competing or are unwilling or unable to respond. When implementing strategy, competitive advantage results out of the way firms perform discrete activities such as conceiving ways to conduct activities, employing new procedures, new technology or different inputs. It is gained by offering consumers greater value by means of lower prices or by providing greater benefits and services that justify higher prices.

\subsection{Commercial Banks of Kenya}

The banking industry in Kenya is governed by the Companies Act (Cap 486), the Banking Act, the Central Bank of Kenya Act and the various prudential guidelines issued by the Central Bank of Kenya (2017). The industry comprises of 43 commercial banks, 2 mortgage finance companies and 123 foreign exchange bureaus (Central Bank of Kenya, 2018). The CBK places commercials banks in Kenya in four major categories based on the ownership: foreign owned locally incorporated, institutions with government participation, foreign owned but locally incorporated institutions (partly owned by locals) and locally owned institutions (Central Bank of Kenya, 2018). Three of the commercial banks have however been placed under receivership by the regulator after experiencing some financial challenges. The study will therefore consider forty (40) banks that are operating with the direct control of Central Bank of Kenya.

The banking sector in Kenya has experienced increasing competition over the years whereby commercial banks have been competing amongst themselves and also other financial institutions (Kungu, Desta, \& Ngui, 2014). At the same time, the Central Bank of Kenya (2020) indicate that there has been high fluctuation in the level of competitive advantage achieved by individual banks in the last five years (2016-2020) with several banks being ranked in different positions over the same period. The Banking Act chapter 48 requires banks to publish their results and bank charges which exposes each bank to imitation by the rivals in the same industry (Central Bank of Kenya, 2015). Most studies done in the banking sector in Kenya have laid emphasis on the strategies the banks need to adopt to gain competitive advantage (Gudmundsson, Ngoka-Kisinguh, \& Odongo, 2013).

The banking sector entered the year 2020 on a strong footing poised to rebound after the interest rate capping was repealed (Central Bank of Kenya, 2020). This was however short-lived since the coronavirus (COVID-19) pandemic that was to define the year 2020, did not feature in the global discourse. When the pandemic struck the banking sector and other players instituted measures to mitigate against the adverse impact. These measures were intended to facilitate the use of digital 
banking services to reduce the infection risk and ensure continued operation of the sector while safeguarding the health and safety of bank staff, customers and the public. The sector remained stable and agile; demonstrating resilience in 2020 despite the COVID-19 pandemic the gross loans and advances grew by $7.2 \%$ by the end of the year.

\subsection{Statement of the Problem}

Gwahula (2013) stated that commercial banks play an important role in the socioeconomic development in both developed and developing countries by ensuring prudent allocation as well as efficient utilization of resources. They are continuously helping to channel funds from depositors to investors as well as providing access to a nation's payment system (Ongore \& Kusa, 2013). However, rapid change, hyper competition, changing demographics and customer needs require banks to build adaptability competency for survival and fostering organizational performance (Central Bank of Kenya, 2018).

Serieux (2008) noted that the financial systems in Africa and in Kenya specifically were shallow and fragile and hence unable to effectively contribute to economic development. The shallowness and fragility the author further observed was reflected in low lending levels, high interest spread, high levels of non-performing loans and failing of several banks. Upadhyaya (2011) argues that this has led to poor performance of the commercial banks. While Oloo (2011) noted that several commercial banks were declaring losses in their financial reports. This was further affirmed by Onuonga (2014) who stated that the performance of commercial banks in Kenya was not impressive and profitability was on average erratic. This has necessitated the banking institutions to adopt competitive intelligence strategies in order to remain competitive and maintain their industry positions.

Wright, Bisson, and Duffy (2012) state that in order to enter, survive and develop in their industry and markets, firms have to gain competitive advantage. Gračanin, Kalac, and Jovanović (2015) state that competitive intelligence can be a source of competitive advantage, enabling a company to develop and implement strategies that improve business efficiency and effectiveness. One of the ways of gaining this competitive advantage in the market is the application of competitive intelligence strategies in enterprises. Wright (2010) noted that competitive intelligence strategies provide a firm with an objective review of the market place; reduces decision making time; minimizes risks and avoid surprises; helps in identification of opportunities before competition does; identification of early warning signals of competitors moves and reduction of uncertainty. Waithaka (2016) found that competitive intelligence practices significantly affected the performance of firms listed on the Nairobi securities exchange. Ngugi, Gakure, and Mugo (2012) in an empirical study found the existence of a high correlation between competitive intelligence practices and profitability of firms in the banking industry in Kenya. This study sought to determine the effect of competitive domains on sustainable competitive advantage among commercial banks in Kenya.

\subsection{Objective of the Study}

To establish the effect of assessing and hedging against key vulnerabilities on competitive advantage among commercial banks in Kenya.

\subsection{Research Hypothesis}

$\mathrm{H}_{01}$ : Assessment and hedging against key vulnerabilities have no effect on competitive advantage among commercial banks in Kenya.

\subsection{Significance of the Study}

This study will be of significance to the management of the banking institutions as it will enable them gain insights on the importance of identifying, assessment and hedging against key vulnerabilities for sustained competitive advantage for their banks. Central bank as the regulator of all the organizations in the banking industry will also gain an understanding on the policies they should 
formulate to allow the banks to gain competitive advantage. The study has made a contribution to empirical knowledge in this discipline which future researchers can use as a basis for their studies.

\section{Literature Review}

This section presents both theoretical and empirical literature relevant to the study that has been reviewed.

\subsection{Dynamics Capability-Based Theory}

Dynamics Capability-Based Theory advocates for competing on capabilities or competencies rather than making traditional resources investments as a more appropriate method for achieving competitive advantage. Day and Nedungadi (1994) argue that a company should be viewed as a bundle of competencies or capabilities as well as resources. In a broad sense, capabilities refer to the organizational processes by which available resources are developed, combined, and transformed into values offered in the market. Teece, Pisano, and Shuen (1997) conceptualized dynamic capabilities as idiosyncratic factors which give rise to sustainable competitive advantage.

In order to achieve competitive advantage and superior performance in the marketplace, especially where the competitive landscape was found to be shifting, companies should identify, seek, develop, and enhance dynamic capabilities (Fielding, 2006). Dynamic capabilities transform resources into new sources of competitive advantage, as they are processes that enable companies to obtain new resource configurations and generate new and innovative forms of competitive advantage. They also embrace collective learning in the organization, especially how to coordinate diverse production skills and integrate multiple stream of technologies. Eisenhardt and Martin (2000) perceive dynamic capabilities as the organizational and strategic routines by which companies achieve new resources configurations as markets emerge, collide, split, evolve and die.

Dynamic capabilities enable an organization to integrate, reconfigure, gain and release resources to match and even create market change (Wang \& Ahmed, 2007). These dynamic capabilities could be functional capabilities, to do with focusing on the increases of functional knowledge and routines, such as performing distribution logistics and advertising campaigns more efficiently than competitors; and integrative capabilities, to do with combining different functional capabilities together with external resources and using them effectively. Some authors suggest that organizational learning, innovation and adaptation to the environment play an important role in the evolution of companies and industries (Barnett \& Burgelman, 1996).

The study is anchored on this theory since both human and organization capabilities are necessary in the process of collecting information and converting it into actionable intelligence. Competitive intelligence domains enhance a firm's ability in developing actionable foresight regarding competitive dynamics and non-market factors that can be used to enhance competitive advantage. Competitive dynamics refers to the evolution of a firm's industry, and the moves and countermoves of the competitors, suppliers, customers, alliance partners, and potential competitors. Competitive intelligence domains enables firms collect information on these players in its environment and formulate strategies to cope with them. Dynamics capability allows a firm to anticipate market developments by carefully monitoring critical events in the environment. This could occur through talking to customers, suppliers, industry experts and other knowledgeable parties.

\subsection{Key Vulnerabilities and Competitive Advantage}

Charles and Gareth (2010) noted that there are three related vulnerabilities that could lead to business failure: inertia, prior strategic commitments and the Icarus paradox. These authors observed that when a company loses its competitive advantage, its profitability falls. The company does not necessarily fail; it may just have average or below-average profitability. It could remain in this mode for a considerable time, although its resource and capital base is shrinking. Some of these firms which all at one time were held up as examples of managerial excellence have gone through periods where their 
financial performance was poor and they clearly lacked any competitive advantage. Collis and Montgomery (1995) argue that sustained competitive advantage is not derived from a fixed stock of competence. Rather, it is the result of continuous competence accumulation, which generates and replenishes the barriers to imitation that permit sustainability of competitive advantage over competitors.

Inertia is another area where firms can be found vulnerable. The inertia argument says that companies find it difficult to change their strategies and structures when adapting to changing competitive conditions. This problem occurs to firms that have been successful in the past that may be brought about by new innovations which may cause a shift in the industry that may lead to diminishing market and lay-off of employees as it unable to cope. Barney (1991) state that companies find it so difficult to adapt to new environmental conditions seems to be the role of capabilities in causing inertia. Organizational capabilities - the way a company makes decisions and manages its processes - can be a source of competitive advantage, but they are difficult to change.

Charles and Gareth (2010) found firms that had prior strategic commitments suffered vulnerability. A company's prior strategic commitments not only limit its ability to imitate rivals but may also cause competitive disadvantage. International Business Machines (IBM), for instance, had major investments in the mainframe computer business, so when the market shifted, it was stuck with significant resources specialized to that particular business. International Business Machines IBM's manufacturing facilities were geared to the production of mainframes. Its research organization and sales force were similarly specialized. Because these resources were not well-suited to the newly emerging personal computer business, IBM's difficulties in the early 1990 s were, in a sense, inevitable. Its prior strategic commitments locked it into a business that was shrinking. Shedding these resources was bound to cause hardship for all organization stakeholders.

Miller (1990) postulated that the roots of competitive failure can be found in what he termed the Icarus paradox. Icarus was a figure in Greek mythology that used a pair of wings that his father made for him to escape from an island where he was being held prisoner. He flew so well that he went higher and higher, ever closer to the sun, until the heat of the sun melted the wax that held his wings together, and he plunged to his death in the Aegean Sea. According to Charles and Gareth (2010) the paradox is that his greatest asset, his ability to fly, caused his demise. Miller argues that the same paradox applies to many once successful companies. According to Miller, some companies become so dazzled by their early success that they believe more of the same type of effort is the way to future success. As a result, they can become so specialized and inner-directed that they lose sight of market realities and the fundamental requirements for achieving a competitive advantage. Sooner or later, this leads to failure.

Nwokah and Ondukwu (2009) examined the relationship between competitive intelligence and marketing effectiveness in corporate organizations in Nigeria. Key vulnerabilities were found to be positively correlated to marketing effectiveness. Teo and Choo (2001) reported that in Singapore the external use of internet for competitive intelligence activities positively related to competitive intelligence which in turn positively impacted on firm performance in terms of revenue generation, cost reduction and managerial effectiveness. Safarnia et al. (2011) in a study to review competitive intelligence and competitive advantage in industrial estates companies in Kerman city using the same strategic inputs of competitive intelligence found a strong relationship between competitive intelligence of corporate organizations and competitive advantage.

Ade, Akanbi, and Ismail (2017) investigated the influence of assessment and hedging against key vulnerabilities on business competitive advantage a case of diamond bank and found a strong direct correlation. The study also found that assessment and hedging firms where they were most vulnerable had significant influence of business competitive advantage.

\section{Research Methodology}

This study adopted both descriptive and explanatory research designs. Descriptive studies sought to answer who, what and how questions whereas explanatory research design is about identifying the 
boundaries of the environment in which the problems, opportunities and situations of interest reside and to identify the salient factors that may be found there that are relevant to the research (Babbie, 2002). Mugenda and Mugenda (2003) stated that descriptive design is the process of collecting data in order to test hypothesis or to answer questions on the current status of the subject under study. Descriptive research design approach is credited due to the fact that it allows analysis on the relationship between variables (Creswell, 1999).

The target population for the study was all the commercial banks in Kenya. There are 43 licensed commercial banks that operate in the country but three have been placed under statutory management by the regulator, which is the Central Bank of Kenya. These three banks were not included in this study as their operations are under the regulators and not the managers per se, therefore the population were 40 of the commercial banks. Hence, the unit of analysis in this study was those commercial banks. A census study of those 40 commercial banks was carried out. The population of 40 respondents meets the threshold size of thirty (30) recommended by Mugenda and Mugenda (2003) as ideal to allow normal approximations. The study targeted the manager or director in-charge of planning / strategy in each firm as the unit for observation. Those are the experts in the subject matter within the firm and are believed to be responsible for activities responsible for monitoring competitors' moves in their firm; therefore they were best positioned to provide information for this study. Primary data was collected using a semi-structured questionnaire which was tested for validity and reliability and found to meet set threshold.

Descriptive statistics such as mean scores, standard deviations, percentages, and frequency distribution were computed to describe the characteristics of the variables of interest in the study. Qualitative response were categorized, coded and grouped into themes that emerge and then triangulated with quantitative data of the study. The research hypothesis was tested at $95 \%$ level of confidence in order to enable the drawing of conclusions. If the p-value is less than $5 \%$, the null hypothesis failed to be accepted and the alternate hypothesis failed to be rejected. If the p-value was greater than 5 percent, the null hypothesis failed to be rejected and the alternate hypothesis will fail to be accepted. As suggested by Muthen and Muthen (2007), inferential statistics such as correlation and regression analysis was used to establish the nature and magnitude of the relationships between the variables and to test the hypothesized relationships. A multiple regression model was adopted as follows:

$\mathrm{Y}=\beta_{0}+\beta_{1} \mathrm{X}_{1}+\varepsilon$

Where: $\mathrm{Y}=$ Competitive Advantage.

$\beta=$ Coefficient.

$\mathrm{X}_{1}=$ Key Vulnerabilities.

$\varepsilon=$ Error term.

\section{Findings and Discussions}

In the course of the study, a total of 40 questionnaires were distributed to managers or directors-incharge of planning / strategy in each of the 40 commercial banks operating in Kenya. Out of these questionnaires, 31 of them were completely filed up and returned by these respondents. This was equivalent to a $77.5 \%$ response rate which was in line with Yin (2017) who recommended that an over $70 \%$ response rate as sufficient for presentation of the findings.

Most $(71 \%)$ of the respondents were male. Majority (52\%) of the respondents had bachelor's degrees as their highest level of academic qualifications, while (39\%) had master's degrees as their highest level of academic qualifications. Those with $\mathrm{Ph}$. D as their highest level of education were only three per cent $(3 \%)$. The position held by the highest number (35\%) of the respondents was strategy managers, closely followed by planning managers (29\%) and director planning (26\%). Most (52\%) of the respondents had worked for 6-10 years in their current positions, only $13 \%$ had worked for less than 5 years.

From the findings above, it can be inferred that respondents of the study were educated and thus had knowledge on how to read and understand the research items in the questionnaire. It can also be deduced that respondents of the study had worked in their respective organizations for a long period of 
time and thus were knowledgeable. The other inference drawn from the above findings is that respondents who took part in the study were generally in managerial position which in most cases deals with the formulation of key strategies including competitive intelligence and thus they were knowledgeable and quite informed.

Twenty six percent (26\%) of the banks had been in operation for a period of 11-15 years and majority, (55\%) are Tier III banks. Most of the banks studied (42\%) had 301-400 employees and spend less than 10 Million shillings annually as competitive intelligence activities budget. Twenty nine (29\%) had over 41 branches and frequently at (58\%) collect and analyse information on competitive intelligence. This shows that majority of the studied banks were stable and had invested in competitive intelligence as a way of remaining competitive.

Table-1.

Vulnerabilities and competitive advantage.

\begin{tabular}{|c|c|c|}
\hline & Mean & Std. Dev. \\
\hline $\begin{array}{l}\text { Firm continuously evaluates its processes to keep abreast with industry } \\
\text { changes }\end{array}$ & 3.90 & 0.746 \\
\hline Flexibility enables the firm to cope with changes in the business environment & 3.97 & 0.875 \\
\hline Employees are continuously trained in new ways of doing business. & 4.19 & 0.885 \\
\hline The firm is constantly following the changes in market trends & 3.92 & 0.814 \\
\hline The firm operates in a very dynamic environment & 3.39 & 0.615 \\
\hline Management regularly assesses and prioritizes the risks faced by the firm & 4.17 & 0.885 \\
\hline The industry the firm operates in has many uncertainties & 3.94 & 0.814 \\
\hline Management regularly assesses and prioritizes the threats faced by the firm & 3.84 & 1.186 \\
\hline
\end{tabular}

Table 1 indicates the results of the analysis done using means and standard deviations from questions that were designed on a five-point Likert scale. The results indicate that employees are continuously trained in new ways of doing business (Mean $=4.19 ; \mathrm{SD}=0.885$ ) and that the management regularly assesses and prioritizes the risks faced by the firm as shown by (Mean=4.17; $\mathrm{SD}=0885)$. They indicate that flexibility enables the firm to cope with changes in the business environment (Mean=3.97; $\mathrm{SD}=0.875)$. They show that the industry in which the firm operates in has many uncertainties (Mean=3.94; $\mathrm{SD}=0.814$ ) and that the firm was constantly following the changes in market trends (Mean $=3.92 ; \mathrm{SD}=814)$. The results show that the firm continuously evaluates its processes to keep abreast with industry changes (Mean $=3.90 ; \mathrm{SD}=0.796)$ and that management regularly assesses and prioritizes the threats faced by the firm (Mean 3.84: $\mathrm{SD}=1.186$ ). The respondents stated that the firm operates in a very dynamic environment (Mean=3.39; $\mathrm{SD}=0.615$ ). A high mean shows that the respondents agree with the statement. The means of most of the statements are above 3.80 showing that respondents agreed on them. A low standard deviation indicates high clustering around the mean of the distribution.

Table-2.

Regression coefficients

\begin{tabular}{|c|c|c|c|c|c|}
\hline & \multicolumn{2}{|c|}{ Unstandardized Coefficients } & \multirow{2}{*}{$\begin{array}{c}\begin{array}{c}\text { Standardized } \\
\text { Coefficients }\end{array} \\
\text { Beta }\end{array}$} & \multirow[b]{2}{*}{$\mathbf{t}$} & \multirow[b]{2}{*}{ Sig. } \\
\hline & $\boldsymbol{\beta}$ & Std. Error & & & \\
\hline (Constant) & 11.194 & 4.527 & & 2.473 & 0.021 \\
\hline Key vulnerabilities & 1.644 & 0.148 & 0.014 & 0.30 & 0.000 \\
\hline
\end{tabular}

The research hypothesis was tested at $95 \%$ level of confidence; if the p-value was less than $5 \%$, the null hypothesis failed to be accepted. The hypothesis also stated that $\beta=0$, meaning that there was no relationship between the two variables as the slope was zero. The results in Table 2 shows that the $p$ value $=0.000$ which is less than 0.05 , key vulnerabilities had a $\beta=1.644$ which is significantly higher than 
zero and constant of $\beta=11.194$ which is significantly different from zero. This indicates that identification and hedging against threats on key vulnerabilities has a positive and significant effect on competitive advantage. The findings indicate that when identification and hedging against key vulnerabilities is increased by 1 unit competitive advantage of commercial banks rises by 1.644 units. Qiu (2008) found that proactive monitoring and scanning of the environmental through the use of competitive intelligence domains would provide critical information on the customer needs and competitors actions that would enable management to better assess the strengths and weaknesses of their organization and subsequently lead to better achievement of competitive advantage. The identification and hedging against key vulnerabilities was found to have significant effect on competitive advantage among commercial banks. Collis and Montgomery (1995) argue that sustained competitive advantage is not derived from a fixed stock of competence rather; it is the result of continuous competence accumulation, which generates and replenishes the barriers to imitation that permit sustainability of competitive advantage over competitors

The findings on the hypothesis indicated that key vulnerabilities have significant effect on competitive advantage among commercial banks. The study revealed that employees are continuously trained in new ways of doing business and that the management regularly assesses and prioritizes the risks faced by the firm. Flexibility enables the firm to cope with changes in the business environment, the industry the firm operates in has many uncertainties, the firm is constantly following the changes in market trends and it continuously evaluates its processes to keep abreast with industry changes. Management regularly assesses and prioritizes the threats faced by the firm. The findings agree with Nwokah and Ondukwu (2009) who found a significant and positive association between key vulnerabilities and competitive advantage in corporate firms in Nigeria.

\section{Conclusions of the Paper}

Identification, assessment and hedging against key vulnerabilities have significant effect on competitive advantage among commercial banks. Continuous assessment of where the banks are vulnerable enables management to hedge the organization against attack by rivals. The identification and assessment of key vulnerabilities would help banks to detect threats and overcome organizational inertia change which makes it difficult to their strategies and structures when adapting to changing competitive conditions. It would also enable banks to make sense of the state of their environment, to adopt new technologies and organizational attributes and contribute to their resilience to make it well suited for emerging trends and threats.

Assessment of key vulnerabilities would strengthen the banks' ability in developing actionable foresight regarding competitive dynamics and non-market factors that could be used to enhance competitive advantage. The identification and assessment of key vulnerabilities allows a banks to remain cognizant of competitor's intentions and anticipate market developments by carefully monitoring critical events in the environment that would expose its vulnerable points.

\section{Recommendations}

Identification and assessment of key vulnerabilities were found to have significant effect on competitive advantage among commercial banks. In view of this finding, the study recommends that the management of commercial banks should be keen to focus on determination of key vulnerabilities as this has significant effect on competitive advantage. This would help management to avoid being innerdirected that they lose the sight of the market realities and the fundamental requirements of achieving competitive advantage.

Bank managers should increase the frequency and scope of competitive intelligence activities that would enable them obtains critical information for rapid identification and assessment of threats to key vulnerabilities so that they can hedge the banks against attack by rivals to the detriment of their performance and competitive advantage. The employees should continuously be sensitized and trained in new ways of collecting intelligence and the management should regularly assess and prioritize the 
identification and assessment of key vulnerabilities. Future studies should be carried out with a focus on related financial institutions such as Micro finance institutions.

\section{References}

Ade, K. L. P., Akanbi, A. M., \& Ismail, T. A. (2017). The influence of marketing intelligence on business competitive advantage (A study of diamond bank Plc). Journal of Competitiveness, 9(1), 51-71. Available at: https://doi.org/10.7441/joc.2017.01.04.

Alaa, M., \& James, S. (1996). The changing basis of performance measurement. International Journal of Operations \& Production Management, 16(8), 63-80. Available at: https://doi.org/10.1108/01443579610125787.

Babbie, E. R. (2002). The basics of social research (9th ed.). Belmont, CA: Wadsworth Thomson Learning.

Barnett, P. W., \& Burgelman, A. R. (1996). Evolutionary perspectives on strategy. Strategic Management Journal, 17, 5-19.

Barney, J. (1991). Firm resources and sustained competitive advantage. Journal of Management, 17(1), 99-120. Available at: https://doi.org/10.1177/014920639101700108.

Central Bank of Kenya. (2015). Bank supervision annual report. Nairobi, Kenya: Central Bank of Kenya.

Central Bank of Kenya. (2017). Bank supervision annual report. Nairobi, Kenya: Central Bank of Kenya.

Central Bank of Kenya. (2018). Bank supervision annual report. Nairobi, Kenya: Central Bank of Kenya.

Central Bank of Kenya. (2020). Bank supervision annual report. Nairobi, Kenya Central Bank of Kenya.

Charles, W. L. H., \& Gareth, R. J. (2010). Strategic management theory: An integrated approach (9th ed.). Mason: South- Western Cengage.

Collis, D. J., \& Montgomery, C. A. (1995). Competing on resources: Strategy in the 1990s. Knowledge and Strategy, 73(4), $25-40$.

Creswell, J. W. (1999). Mixed method research: Introduction and application. In T.Cijek (Ed.), Handbook of educational policy (pp. 455-472). San Deigo, CA: Academic Press.

Day, G. S., \& Nedungadi, P. (1994). Managerial representations of competitive advantage. Journal of Marketing, 58(2), 31-44. Available at: https://doi.org/10.1177/002224299405800203.

Deng, Z., \& Luo, L. (2010). An exploratory discussion of new ways for competitive intelligence on the Web 2.0. International Federation for Information Processing, 252(1), 597-604. Available at: https://doi.org/10.1007/978-0-387-75494-9_72.

Eisenhardt, K. M., \& Martin, J. A. (2000). Dynamic capabilities: What are they? Strategic Management Journal, 21(10-1 1), 11051121.

Fahey, L. (2007). Connecting strategy and competitive intelligence: Refocusing intelligence to produce critical strategy inputs. Strategy Leadership, 35(1), 4-12. Available at: https://doi.org/10.1108/10878570710717236.

Fielding, M. (2006). Leadership, radical students engagement and the necessity of Person-Centered education. International Journal of Leadership in Education, 9(4), 299-313. Available at: https://doi.org/10.1080/13603120600895411.

Fleisher, C. (2001). An introduction to the management and practices of competitive intelligence (CI)", in Fleisher, C.G. and Blenkhorn, D.L. (Eds), Managing Frontiers in Competitive Intelligence (pp. 3-18). Westport, CT: Quorum Books.

Garelli, S. (2003). Competitiveness of nations: The fundamentals. Retrieved from: http://www.imd.org/uupload/www01/documents/wcc/content/fundamentals. [Accessed 20 February 2018 ].

Gračanin, Š., Kalac, E., \& Jovanović, D. (2015). Competitive intelligence: Importance and application in practice. Review of Innovation and Competitiveness: A Journal of Economic and Social Research, 1(1), 25-44. Available at: https://doi.org/10.32728/ric.2015.11/2.

Griffith, S. E. (1971). Sun tsu: The art of war. New York: Oxford University Press.

Gudmundsson, R., Ngoka-Kisinguh, K., \& Odongo, M. T. (2013). The role of capital requirements on bank competition and stability: The case of the Kenyan banking industry. Kenya Bankers Association, Working Papers Series, No. 02, 2-5.

Gwahula, R. (2013). Efficiency of commercial banks in East Africa: A non parametric approach. International Journal of Business and Management, 8(4), 50-64. Available at: https://doi.org/10.5539/ijbm.v8n4p50.

Heppes, D. W. (2006). An assessment of the level of maturity of the competitive intelligence function within a South African retail bank. Doctoral Dissertation, University of Johannesburg.

Kalinowski, D. (2012). Positioning for growth in emerging markets. Proacfive Worldwide, 15(3), 10-16.

Kotler, P., \& Kelley, K. (2006). Marketing management (12th ed.). New Jersey: Pearson Educational Incorporated.

Kungu, G., Desta, I., \& Ngui, T. (2014). An assessment of the effectiveness of competitive strategies by commercial banks: A Case of Equity Bank. International Journal of Education and Research, 2(12), 333-346.

Laudon, K. C., \& Laudon, J. P. (2007). Essentials of business information systems (7th ed.). Upper Saddle River, N.J: Pearson Prentice Hall.

Levy, M., \& Weitz, B. (2001). Retailing management (4th ed.). New York: McGraw-Hill Companies Inc.

Liao, S.-H., \& Hu, T.-C. (2007). Knowledge transfer and competitive advantage on environmental uncertainty: An empirical study of the Taiwan semiconductor industry. Technovation, 27(6-7), 402-411. Available at: https://doi.org/10.1016/j.technovation.2007.02.005.

Ma, H. (2000). Competitive advantage and firm performance. Competitiveness Review, 10(2), 16-17.

McCandles, B. (2003). Controversies in competitive intelligence: The enduring issues. Westport, CT: Praeger Publishers.

Miller, D. (1990). The icarus pradox. New York: Harper Business. 
Mugenda, O. M., \& Mugenda, A. G. (2003). Research methods: Qualitative and quantitative approaches. Nairobi, Kenya: African Centre for Technology Studies.

Muthen, L. K., \& Muthen, B. O. (2007). Mplus user's guide (7th ed.). Los Angeles, CA: Muthén \& Muthén.

Nenzhelele, T. E. (2012). A study of the awareness and practice of competitive intelligence in SMEs in the city of Tswana metropolitan municipality. Unpublished Maters Thesis at the University of South Africa.

Ngugi, J. K., Gakure, R. W., \& Mugo, H. (2012). Competitive intelligence practices and their effect on profitability of firms in the Kenyan Banking Industry. International Journal of Business and Social Research, 2(3), 11-18.

Nwokah, N. G., \& Ondukwu, F. (2009). Competitive intelligence and marketing effectiveness in corporate organizations in Nigeria. African Journal of Marketing Management, 1(1), 010-022.

Oloo, O. (2011). Banking survey report, the best banks this decade 2001-2010. Kenya: Think Business Limited.

Ongore, V. O., \& Kusa, G. B. (2013). Determinants of financial performance of commercial banks in Kenya. International Journal of Economics and Financial Issues, 3(1), 237-252.

Onuonga, S. M. (2014). The analysis of profitability of Kenyas top six commercial banks: Internal factor analysis. American International Journal of Social Science, 3(5), 94-103.

Pertisor, I., \& Strain, N. A. (2013). Approaches on competitive intelligence. The USV Annals of Economics and Public Administration, 1(17), 100-109.

Pirttimaki, V., \& Hannula, M. (2003). Finnish experience of business intelligence practices. Paper presented at the International Conference on Business Intelligence, Oct, Victoria, Museo Artium, Franciaw.

Pirttimäki, V. (2007). Comparative study and analysis of the intelligence activities of large Finnish companies. Journal of Competitive Intelligence and Management, 4(1), 147-170.

Porter, M. E. (1996). Competitive advantage, agglomeration, economic and regional policy. International Regional Science Review, 19(1\&2), 85-94. Available at: https://doi.org/10.1177/016001769601900208.

Prescott, J. E. (1999). Evolution of competitive intelligence. Competitive Intelligence Revier, Spring, 37-52.

Qiu, T. (2008). Scanning for competitive intelligence: A managerial perspective. European Journal of Marketing, 42(7/8), 814835. Available at: https://doi.org/10.1108/03090560810877178.

Ray, G., Barney, J. B., \& Muhanna, W. A. (2004). Capabilities, business processes, and competitive advantage: Choosing the dependent variable in empirical tests of the resource-based view. Strategic Management Journal, 25(1), 23-37. Available at: https://doi.org/10.1002/smj.366.

Roitner, A. (2008). Competitive intelligence in Austria: An empirical study. A Thesis for MAfrom the Department of Sociology and Economics, Wien University, Germany.

Safarnia, H., Akbari, Z., \& Abbasi, A. (2011). Review of competitive intelligence \& competitive advantage in the industrial estates companies in the Kerman City: Appraisal and testing of model by Amos graphics. International Business and Management, 2(2), 47-61.

Serieux, J. (2008). Financial liberalization and domestic resource mobilization in Africa: Assessment. International Poverty Centre Working Paper, No. 45.

Teece, D. J., Pisano, G., \& Shuen, A. (1997). Dynamic capabilities and strategic management. Strategic Management Journal, $18(7), 509-533$.

Teo, H. L., \& Choo, W. Y. (2001). Assessing the impact of using internet for competitive intelligence. Information and Management, 39(1), 67-83. Available at: https://doi.org/10.1016/s0378-7206(01)00080-5.

Upadhyaya, R. (2011). Analyzing the sources and impact of segmentation in the banking sector: A Case study of Kenya. Unpublished Ph.D Thesis Presented to the University of London.

Waithaka, P. (2016). Competitive intelligence practices and performance of firms listed on the Nairobi securities exchange, Kenya. European Scientific Journal, 12(19), 107-126.

Waithaka, P. (2020). Tactics oriented competitive intelligence practice and performance of firms listed on the Nairobi securities exchange, Kenya. International Journal of Science, Arts and Commerce, 5(9), 15-22.

Wang, C. L., \& Ahmed, P. K. (2007). Dynamic capabilities: A review and research agenda. International Journal of Management Reviews, 9(1), 31-51.

Wright, S. (2010). Capitalizing on intelligence: Converting input to output to insight and competitive advantage. Journal of Strategic Marketing, 18(7), 517-521.

Wright, S., Bisson, C., \& Duffy, A. P. (2012). Applying a behavioural and operational diagnostic typology of competitive intelligence practice: Empirical evidence from the SME sector in Turkey. Journal of Strategic Marketing, 20(1), 19-33. Available at: https://doi.org/10.1080/0965254x.2011.628450.

Yin, R. K. (2017). Case study research applications. Design and methods. Thousand Oaks, CA: Sage. 